\title{
Alcohol and society in the arts
}

\author{
Connie Nugent MLS
}

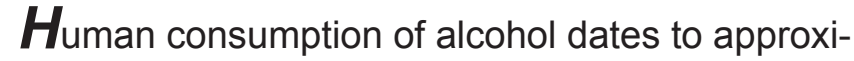
mately 10,000 years ago, as remnants of pottery from the Neolithic period in China revealed evidence of fermented beverage made from honey, rice, and fruit. ${ }^{1}$ Beer made from barley was brewed in Mesopotamia circa $3400 \mathrm{BCE}$, and a variety of fermented liquids date from ca. 3400 BCE in Egypt and India, and from 2000 BCE in Mexico and Greece. ${ }^{2}$ Distillation spread rapidly into Europe; the cult of Dionysus in the 5th century BCE in Italy preferred wine to beer.

Alcohol has physical and psychological effects. According to the Centers for Disease Control and Prevention, "Alcohol affects every organ in the body. It is a central nervous system depressant that is rapidly absorbe . . . into the bloodstream." In moderate doses, alcohol consumption can produce feelings of well-being, but in larger doses can result in serious health problems, "Alcohol intoxication can be harmful for a variety of reasons, including impaired brain function ... increased risk of certain cancers ... damage to a developing fetus ... violence and other injuries." ${ }^{3}$

That alcohol intoxication is a part of life is evident in literature. The earliest mention of alcohol consumption in the Bible occurs in Genesis 9:20-27; after the flood, Noah becomes drunk with wine and falls into a stupor, lying "uncovered."

... And Ham, the father of Canaan, saw the nakedness of his father, and told his two brothers outside. Then Shem and Japheth took a garment, laid it on both their shoulders, and walked backward and covered the nakedness of their father; their faces were turned away, and they did not see their father's nakedness.

Corresponding author: Connie Nugent

Contact Information: Connie.nugent1@gmail.com DOI: $10.12746 /$ swrccc.v6i26.500
Noah, upon wakening, curses Canaan for his father's indiscretion. Biblical scholars suggest that drunkenness itself was not viewed negatively at the time; the fault lies in Ham's failure to respect the honor of his father. ${ }^{4}$

The glitterati portrayed in F. Scott Fitzgerald's The Great Gatsby (1929) are fueled by bootlegged alcohol as they stumble from one lavish party to another, "The bar is in full swing and floating rounds of cocktails permeate the garden outside until the air is alive with chatter and laughter and casual innuendo ... champagne was served in glasses bigger than finger bowls." The extravagant lifestyle cannot hide the wreckage of excessive alcohol consumption. The euphoria resulting from moderate alcohol intake rapidly degrades into feelings of discontent, even despair. In her essay in The Guardian, Sarah Churchill remarks that the novel ". . . is a celebration of intemperance and a condemnation of its destructiveness. It is about trying to recapture our fleeting joys, about the fugitive nature of delight. It is a tribute to possibility, and a dirge to disappointment." ${ }^{6}$

Drinking too much is sometimes the result of fear. In Arthur Miller's play Death of a Salesman (1949), Willy Loman's son Biff is afraid to tell his father that he has ruined a possible chance for an interview by stealing a fountain pen from the desk of the man who might hire him. Miller's stage directions indicate that Biff is now "high, slightly alcoholic, above the earth" as he confronts his father. Willy, lost in his own perception of the situation, continues to interrupt Biff until his son breaks, "Dad, you're not letting me tell you what I want to tell you!"” The subsequent confession does not go well.

While Biff feels the need to be fortified by alcohol to confess his transgression to his father, the effect of alcohol intoxication on family members, especially children, is even more profound. In Eowyn Ivey's novel The Snow Child (2012), married couple Jack 
and Mabel befriend young Faina in snowbound rural Alaska but know nothing about her until one day Faina leads Jack deep into the forested mountain to her camp. There Jack sees a snow-covered heap covered by a tarp. "The corpse lay on its side, curled up like a child, but it was no child." Faina whispers that it is her father. "Jack went to one knee beside the corpse and caught the strong smell of liquor. A green glass bottle was clenched in a frozen claw of a hand. Jack's stomach turned. How could a man do this, drink himself to death in front of his child?" Faina's chin trembles, "I tried. I tried and tried." Jack consoles her, "You aren't to blame. Your papa was a grown man, and no one could have saved him but himself. This is not your fault." ${ }^{8}$ The alcoholic father in Mark Twain's Adventures of Huckleberry Finn (1885) is worse. Having abandoned Huck for several years, he reappears when he learns that his son has come into money. Huck remembers what living with his drunken brutal father was like, "I used to be scared of him all the time, he tanned me so much." Unable to get his hands on Huck's money, eventually his father takes Huck to live in the woods, where "it was kind of lazy and jolly . . . but by-and-by pap got too handy with his hick'ry, and I couldn't stand it. I was all over welts."

As in literature, the effects of alcohol consumption are portrayed in art. In France, "alcoolisme" as a diagnosis was established by 1865 , and a temperance organization attempted to combat this problem that was commonly associated with the working class. ${ }^{10}$ Impressionist Edouard Manet's painting Le Bon Bock, however, became popular among all levels of society. Manet posed his friend Emile Bellot as a contented beer drinker. In this painting, the fear of alcoholism is set aside as drinking seems tranquil and pleasant. A man sits smoking a long-stemmed pipe as his left hand holds the glass of beer that rests upon the tabletop. The jaunty angle of his otter fur hat, his round stomach, his rosy cheeks, and the twinkle in his eyes imply an ambiance of joviality, emphasizing the pleasures of alcohol.

While Le Bon Bock suggests the positive side of enjoying alcohol, Edouard Degas illustrated the opposite in his painting L'Absinthe (The Glass of Absinthe.) He posed his friends actress Ellen Andrée

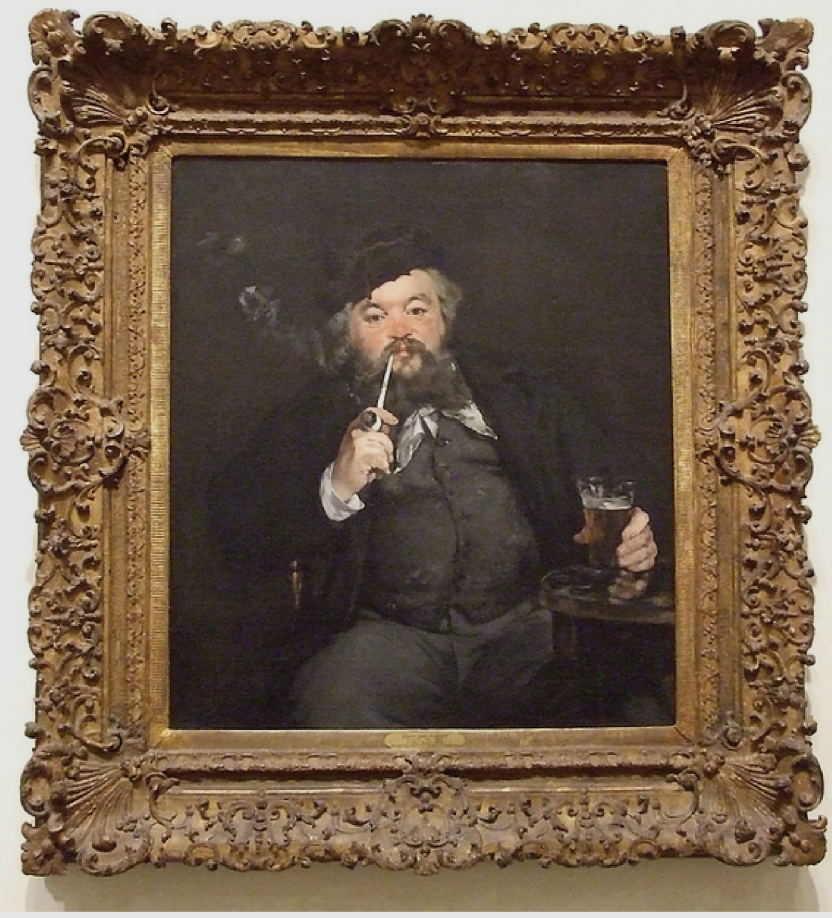

Edouard Manet. Le Bon Bock. (The Good Beer) 1873.

(Portrait of Emile Bellot.) Philadelphia Museum of Art.

and engraver Marcellin Desboutin at the Café de la Nouvelle Athènes as two people disenchanted with life, dependent on alcohol. ${ }^{11}$ Manet placed his figure in the center of Le Bon Bock, looking toward the viewer. The viewer's point of view, then, is that of someone sitting across the table, suggesting an intimate social encounter. Degas shifts his characters off center, placing the café tables between the couple and the viewer, pushing the viewer away, isolating them. The man and woman are seated side by side, but each seems to be trapped in his or her loneliness. At the right edge of the painting, the man gazes toward the interior of the café, perhaps at other drinkers, while the woman drops her eyes toward the glass of absinthe in front of her. The slumping posture of both implies despondency.

Alcohol consumption in Le Bon Bock is celebrated as a social event, while drinking in L'Absinthe points to the darker side of alcoholism. Even the artists' brushstrokes illustrate the difference between moderate social drinking and addiction to alcohol. Both 


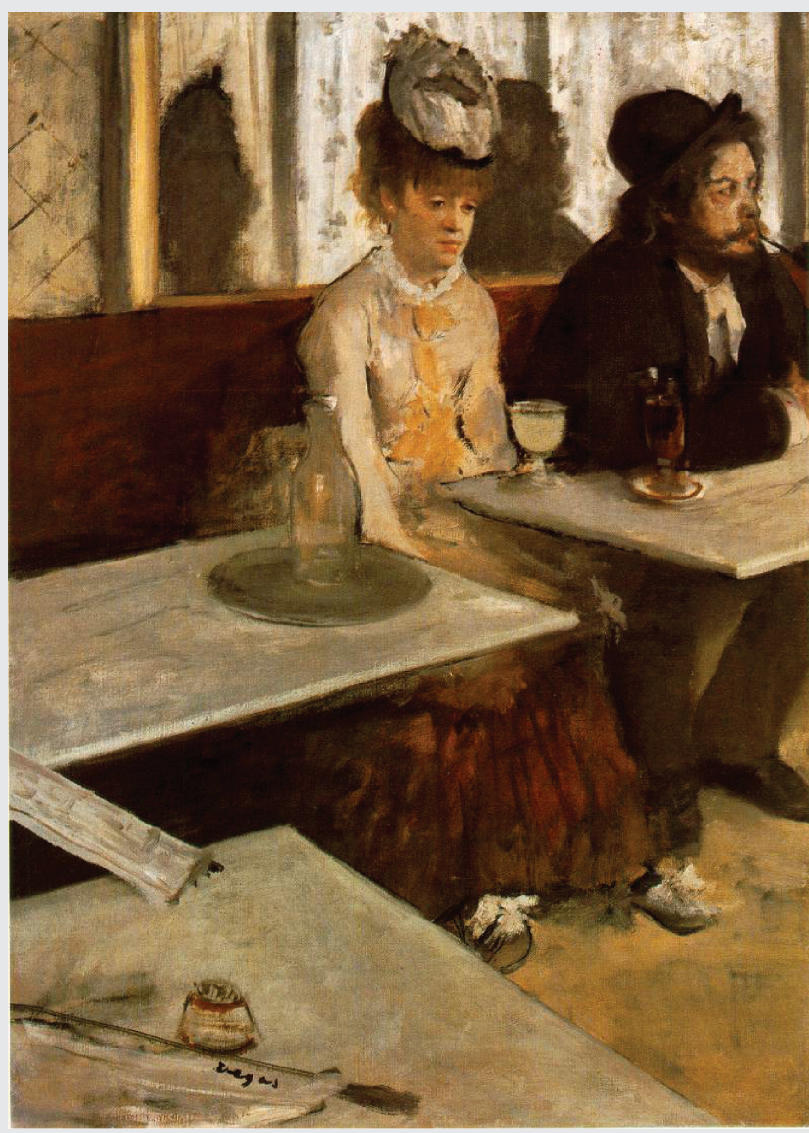

Edgar Degas. L'Absinthe. (The Glass of Absinthe) 1875-76. Musée D’Orsay, Paris

(https://commons.wikimedia.org/wiki/File:Edgar_Degas_-_Absinthe.jpg)

Manet and Degas were Impressionists, so their paintings do not portray objects in precise detail but rely on impressions of experience. Even so, Le Bon Bock's social drinker is clearer than the hazy rendering of the alcohol dependent characters in L'Absinthe.

An earlier article in this Medicine in Art series discussed opioid addiction and its depiction in literature and in paintings. Alcoholism rivals opioid addiction in its effects on the individual, on the family, and on the health care system. Literature and art can help health care providers understand the true impact of alcohol abuse on patients and families.

Keywords: alcohol, literature, paintings, society
From: The Department of Internal Medicine at Texas Tech University Health Sciences Center in Lubbock, Texas

Submitted: 10/2/2018

Conflicts of interest: none

This work is licensed under a Creative Commons Attribution-ShareAlike 4.0 International License

\section{REFERENCES}

1. Malhotra R. "Our Ancestors were drinking alcohol before they were human." BBC News. Feb 23, 2017. http://www.bbc. co.uk/earth/story/20170222-our-ancestors-were-drinkingalcohol-before-they-were-human. Accessed 9/15/18

2. Roach J. "Cheers! Eight ancient drinks uncorked by science." NBC News. http://www.nbcnews.com/id/34435526/ns/technology_and_science-\%20science/t/cheers-eight-ancientdrinks-uncorked-science/\#.W515-hSnVO1. Accessed 9/15/18

3. Centers for Disease Control and Prevention. Alcohol and public health: Frequently asked questions. https://www.cdc. gov/alcohol/faqs.htm. Accessed 9/26/18

4. Coogan MD. The New Oxford Annotated Bible; New Revised Standard Version with the Apocrypha. An Ecumenical Study Bible. $4^{\text {th }}$ ed. New York: Oxford University Press, 2010.

5. Fitzgerald FS. The Great Gatsby. New York; Simon \& Schuster, 1925.

6. Churchill S. "What makes The Great Gatsby great?" The Guardian.U.S.Edition.May3,2013.https://www.theguardian. $\mathrm{com} /$ books/2013/may/03/what-makes-great-gatsby? CMP=twt_gu\&CMP=NECNETTXT766. Accessed 9/26/18

7. Miller A. Death of a Salesman. New York; Viking Press, 1949.

8. Ivey E. The Snow Child. New York; Little, Brown and Company, 2012.

9. Twain M. Adventures of Huckleberry Finn. Riverside Edition by H N Smith. Boston: Houghton Mifflin Company, 1958.

10. King R. The judgment of Paris; the revolutionary decade that gave the world Impressionism. New York; Walker \& Company, 2006.

11. Schneider P. The World of Manet 1832-1883. New York: Time-Life Books, 1968. 